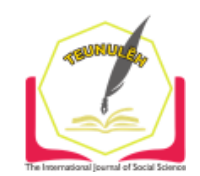

Jurnal Ilmiah Teunuleh

The International Journal of Social Sciences

Vol. 2, Issue. 1, Mar 2021

E-ISSN: 2746-4393

\title{
THE INFLUENCE OF INQUIRY LEARNING METHOD AND SELF- RELIANCE LEARNING ON IPS OUTCOMES IN FOURTH GRADE AT SD NEGERI 060874
}

\author{
Eka Putri Kartini Pasaribu ${ }^{1}$ \\ Samsidar Tanjung ${ }^{2}$ \\ Edidon Hutasuhut ${ }^{3}$ \\ ${ }^{123}$ State University of Medan, Indonesia
}

\begin{abstract}
This study aims to find out the use of inquiry learning models and conventional learning models in student IPS learning outcomes, to know the differences in IPS learning outcomes of students who have high learning independence with students who have low learning independence, and to know the interaction between the learning model and the independence of learning to the student's IPS learning outcomes. This research is a quasiexperimental study with the research population is all grade IV students as many as 60 students with samples are all grade IV students ( $A$ and $B$ ) who take IPS subjects. From the research, it was produced that the inquiry learning model is higher than the use of conventional learning model shown by $F_{\text {count }}=3.86>F_{\text {table }}=2.77$ at a significant level $\alpha=0.05$. IPS learning outcomes of students who have higher learning independence than students who have low learning independence indicated by $F_{\text {count }}=3.74>F_{\text {table }}=2.77$ at a significant level $\alpha=0.05$. There is an interaction between the learning model and the independence of learning to the student's IPS learning outcomes indicated by $F_{\text {count }}=3.64$ $>F_{\text {table }}=2.77$ at a significant level $\alpha=0.05$. The conclusion of this study shows that inquiry learning is better used for students who have high learning independence while conventional learning models are well used for students who have low learning independence in order to have interactions between learning models and self-reliance learning.
\end{abstract}

Keywords: Inquiry Learning Method, Self-Reliance Learning, IPS Learning Outcomes.

\section{A. Introduction}

Education is one of the main instruments of human resource development, educators (teachers) as one of the elements that play an important role in it, have a responsibility to develop tasks and overcome all problems that arise. Teachers are a very 
decisive component in the implementation of both in an education. Education is closely related to the success of the learning process in the classroom as a micro element of an educational success.

Effective learning can be achieved through the management of learning starting from components that in the form of preparing learning conditions and what objectives to achieve in learning, components of good and precise implementation in the form of what lesson materials are needed and which models or tools should be used in teaching and learning activities, as well as what components of procedures will be taken to evaluate.

In Social Sciences (IPS) lessons, teachers teach students how to live interacting, socializing, communicating, and connecting with the environment and with diverse environments, situations and conditions. Students are expected to have a sensitive and responsive attitude to act rationally and responsibly in solving social problems faced in their lives.

The success of IPS learning in the classroom means a lot with the personality of the teacher, therefore in its implementation teachers are required to have skills, tenacity, and an open attitude to students. In addition, teachers are also expected to have the ability to create more active and creative learning situations, so as to provide encouragement and independence of learning to students.

From the observations at SDN 060874, researchers found that the learning conducted by teachers still does not vary in using the right learning model can be seen from the average value of IPS subjects grade IV in 2017-2020 semester I which is 65 and II 67 when the limit of Completion Criteria (KKM) is 75. Based on the data, students were able to achieve a score of $\geq 65$ only $30 \%$ and semester II $33 \%$ of 30 grade IV students, while the rest obtained grades under the Minimum Completion Criteria. This is because almost $70 \%$ of students lack understanding and are less involved in the mastery of the material so that the results of IPS students in grade IV SDN 060874 Medan Perjuangan are relatively low.

Master of teachers in IPS learning to various learning models that are not optimal, lack of interaction between teachers and students during the learning process, lack of creativity of teachers in designing effective learning implementation plans to improve the learning outcomes of IPS and low student learning independence in the learning process. Therefore, a teacher is required to be creative in delivering lesson materials to students. Efforts to improve learning outcomes are not easy to do, but it is the 
The Influence of Inquiry Learning Method and Self-Reliance Learning on IPS Outcomes...

responsibility of the teacher how a student to easily understand the material delivered and what he obtains is something meaningful in his life.

Researchers felt the need to apply a learning model that involves students actively and directly in IPS learning in grade IV students of SDN 060874 Medan Perjuangan. One of the learning models that can be used as an alternative is the incugate learning model. The inquiry learning model is a form of student centered approach that has differences with conventional learning models. The inquiry's learning model emphasizes the critical and analytical thought process of finding and finding answers to a questionable problem for yourself.

\section{B. Method}

This research was conducted at SD Negeri 060874 Medan Perjuangan with the consideration that this school has never conducted research with the same problem and can represent the type of formal school at elementary school level. The research was conducted in November to December 2020 odd semester of the 2020/ 2021 school year. The implementation of this research treatment is tailored to the educational calendar and does not interfere with the scheduled learning process.

The population and samples in this study are all students of grade IV SD Negeri 060874 Medan Perjuangan Tahun Pelajaran 2020 consisting of 2 classes of 60 students, including IVa class consisting of 30 students and class IVb consisting of 30 students.

The research uses quasi-experimentalresearchwith factorial research design $2 \times$ 2. This design will compare the influence of the inquiry learning model with the conventional learning model. The model of inquiry and conventional learning as a free variable, the results of learning IPS as a bound variable and the independence of learning as a moderator variable.

\section{Finding and Discussion}

\section{Finding}

a. Student IPS Learning Outcomes with Inquiry Learning Method

Based on the data obtained from the study it is known that the results of IPS learning that is studied using the inquiry learning method obtained a minimum score of 19 and a maximum score of 33 average values is 27.58 variance $\left(S^{2}\right)$ is 10.65 and the standard deviation (S) is 3.26. The description of the student's IPS learning outcome score data using the inquiry learning model can be described in the following graph: 


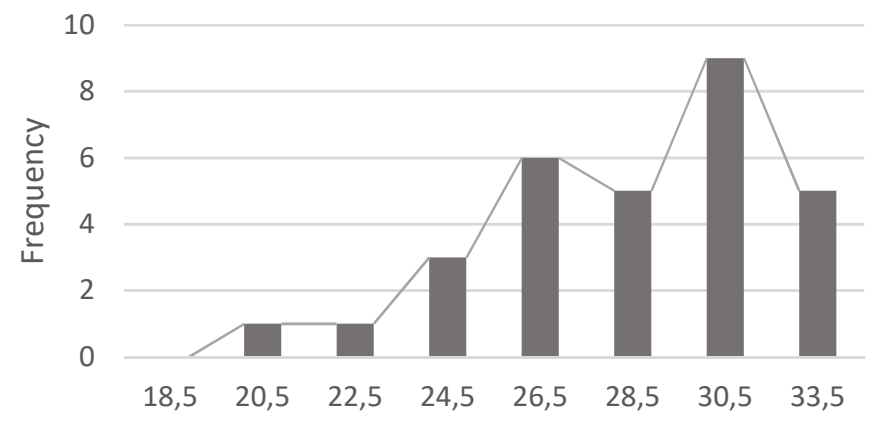

Based on the graph illustrates that the results of IPS learning students are taught using of the learning inquiry method shows learning on the material diversity of natural appearance, the learning atmosphere of students who show high interaction with the application of discussion methods that make the atmosphere of question and answer students who are active and courageous in giving opinions. Students are also given the opportunity to form study groups, all students can work together and eliminate the attitude of individualism in expressing opinions. Students can learn from each other and participate in completing student worksheets.

\section{b. Student IPS learning outcomes using Conventional Learning Model}

From the data obtained it is known, that the results of students' IPS learning are taught using a conventional learning model obtained a maximum score of 30 , the minimum score is 16 the average score is 23.65, the variance $\left(S^{2}\right)$ is 15.70 and the standard deviation (S) is 3.96. The frequency distribution of students' IPS learning outcome scores using conventional learning models is illustrated in the following graph:

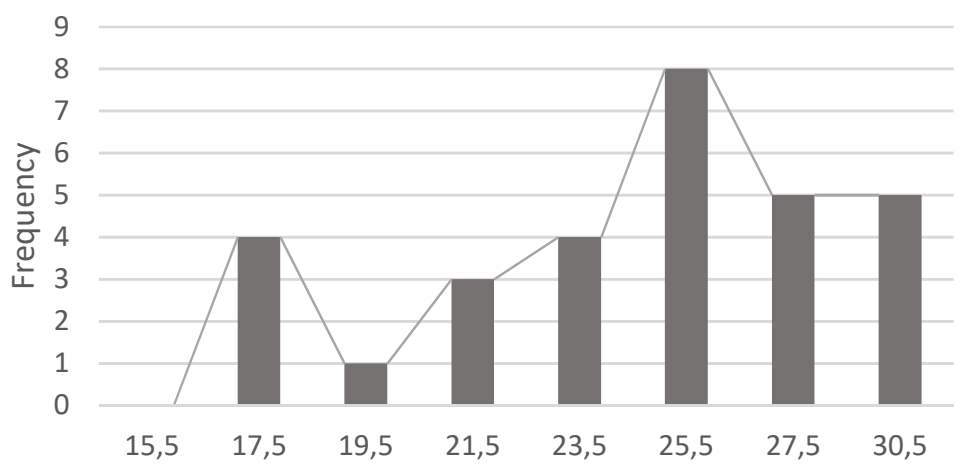

From the graph illustrates that the results of student IPS learning are taught using a conventional learning model, showing the passive learning atmosphere of students and the absence of opportunities for students to find a problem due to the learning of material diversity of natural appearance centered on the teacher. 
The Influence of Inquiry Learning Method and Self-Reliance Learning on IPS Outcomes...

\section{c. IPS Learning Outcomes of Students who have High Self-Reliance Learning}

IPS learning outcome data of students who have high self-reliance learning as follows: the lowest score is 16, the highest is 33 and the average score is 27.38 Furthermore the median score ( $\mathrm{Me}$ ) is 29.7 , the mode (Mo) is 29.88 , variance $\left(\mathrm{S}^{2}\right)$ is 17.23 and the standard deviation (s) is 4.15. The acquisition of this score data can be described through the histogram chart as follows:

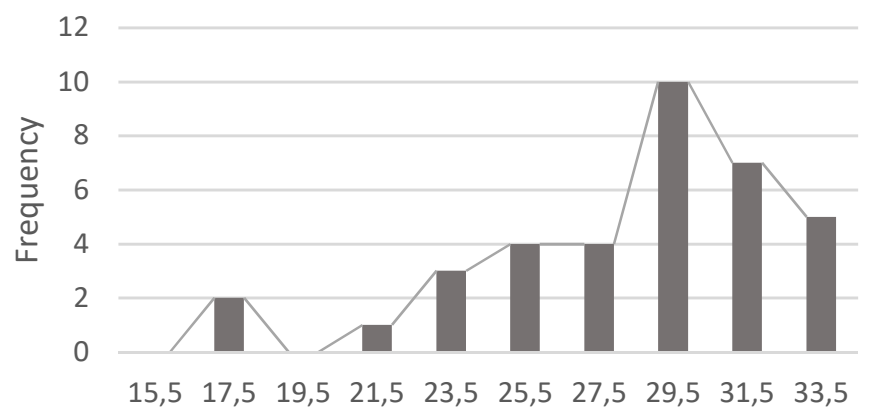

From the graph obtained data on student IPS learning outcomes with the following details: there are 10 students or $27.78 \%$ of students with scores are in the average class, 14 students or $38.89 \%$ are below the class average and 12 students or $33.33 \%$ students are above the class average. High learning independence affects $61.11 \%$ of students' IPS learning outcomes.

\section{d. IPS Learning Outcomes of Students who have Low Self-Reliance Learning}

IPS study results data of students who have low self-reliance learning as follows the lowest score is 17 the highest is 29 and the average score is 22.62 Furthermore the median score (Me) is 25.25 , the mode (Mo) is 25.87 , the variance $\left(\mathrm{S}^{2}\right)$ is 9.67 and the standard deviation (s) is 3.11 . This data can be described through histogram chart as follows:

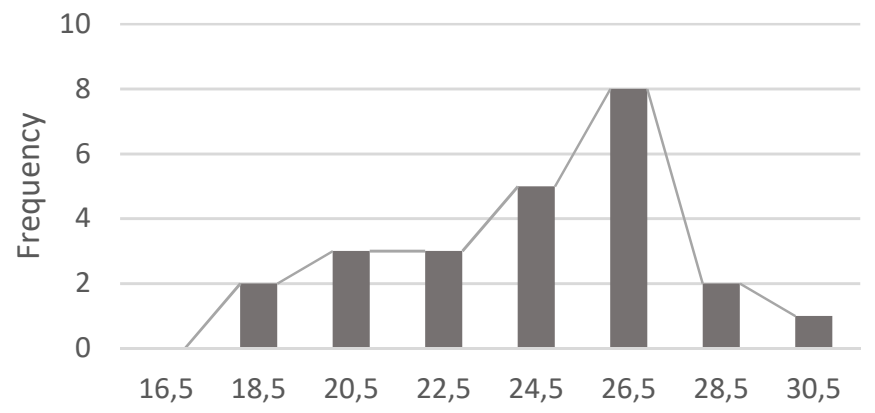

From the graph obtained data on student IPS learning outcomes with the following details: there are 8 students or $33.33 \%$ of students with scores are in the average class, 
13 students or $54.17 \%$ students are below the average class and 3 students or $12.5 \%$ of students are above the class average. Low learning independence affects $45.8 \%$ of students' IPS learning outcomes.

\section{Discussion}

a. Student IPS Learning Outcomes are taught with a Higher Inquiry Learning Method than Student IPS Learning Outcomes that are taught with a Conventional Learning The results showed that students' IPS learning outcomes were taught with a higher inquiry learning model than the students' IPS learning outcomes that were taught with a conventional learning model. The average student's IPS learning outcomes are taught with an inquiry learning model higher than the average student's IPS learning outcomes that are taught with a conventional learning model. Where $\bar{X}_{\text {incugate }}=27.58$ while $\bar{X}_{\text {conventional }}=23.65$. The first hypothesis test obtained $F_{\text {count }}=3.86>F_{\text {table }}=2.77$. Thus, the hypothesis proposed is that students who are taught with an inquiry learning method are higher than the students' IPS learning outcomes that are taught with a conventional learning model accepted.

The findings of this study support the results of research obtained by Widani et al (2019) found that students' learning achievements in inquiry learning are higher than students' learning achievements in conventional model learning, Mince (2017) found that students' IPS learning outcomes in learning using the inquiry learning model are higher than the student's learning outcomes in direct learning, and Roni (2015) found that students' thinking and creative abilities can be developed using an inquiry learning model rather than using traditional learning models.

This is because students in the inquiry learning model group are used to working together in learning and being responsible for one team, and being able to make themselves learn just as well. Therefore, the use of the right learning model will be able to improve students' learning homework, students work as a team to solve a problem, complete an assignment or do something to achieve a common goal. The student is not only responsible for himself or herself but also his group.

The teacher's inquencing learning model has been able to grow and improve students' self-reliance of learning so that students' learning outcomes improve. Especially the award given by teachers to the best groups. The awarding of this award has had a positive effect on students. Students are increasingly enthusiastic to learn. It 
The Influence of Inquiry Learning Method and Self-Reliance Learning on IPS Outcomes...

means that receiving an award will ultimately increase students' independence to do their best.

b. IPS Learning Outcomes of Students Who Have Higher Self-Reliance Learning than IPS Learning Outcomes of Students Who Have Low Self-Reliance Learning

The results showed that the IPS learning outcomes of students who have high selfreliance are higher than the learning outcomes of IPS students who have low self-reliance learning. The average learning outcome of students who have high self-reliance is higher than the learning outcomes of IPS students who have low learning self-reliance. With $\bar{X}_{\mathrm{KT}}=27.38$, and $\bar{X}_{\mathrm{KR}}=22.62$. The first hypothesis test obtained $\mathrm{F}_{\text {count }}=3.74>\mathrm{F}_{\text {table }}=$ 2.77. Thus, the hypothesis proposed is that students who have high independence are higher than the learning outcomes of IPS students who have low self-reliance learning are accepted.

The findings of this study support the results of research obtained by Suharnan (2012) this study aims to develop the scale of self-reliance as a psychological measuring tool that can be used for future studies. The scale of self-reliance has been prepared in accordance with psychometric procedures and consists of a number of items incorporated into four components. The study was conducted through two studies, and involved 331 male and female student subjects from several secondary schools and a university. Aliyyah (2017) found independence has a significant effect on learning achievement, learning achievement of students who have high learning independence is better than the learning achievement of students who have moderate and low learning independence. Research also conducted by Nita (2014) at the high school level shows that the independence of learning positively affects the results of learning History.

Learning independence has several benefits for students. Lipton and Hubble ( (2005, pp. 15-16) stated "The benefit of learning independence is to grow confident and self-governing students. Students grow up in this region when they make choices and make their own decisions about when, how and what their learning assignments look like". In this case the ability of students to make decisions will affect the acquisition of learning outcomes.

In self-learning students will try themselves first to learn and understand the content of the lessons they read or see through the medium of view and hearing. If the student gets into difficulty then the student will ask or discuss with friends, teachers or other parties who if more competent in overcoming the difficulty. Student self-reliance 
will be able to find the necessary learning resources and must have their own initiative creativity and be able to work alone by referring to the guidance they receive.

One of the subjects in primary schools that demands the student self-reliance learning is Social Sciences (IPS). In IPS learning not only wants students to hear the teacher's explanation, but also able to find their own directly. This can be done by stimulating students' curiosity and giving students the opportunity to explore finding answers through various activities. Therefore, the knowledge gained by students can be applied directly in daily life.

The results of the researchers' monitoring during the learning process, it appears that students who are classified as having high learning independence tend to be aware of learning objectives, more responsible, more continuous in learning, more accustomed to being active in learning, and accustomed to learning regularly. Students who have high learning independence also do not feel afraid of wrong or dissent with other students and have more mutual respect. While during the learning process the activities of students who have low learning independence tend to be less attentive, less concentrated, less motivated in learning and less independent than students who have high learning independence.

Based on the description above and supported by the results of research, it can be concluded that if the independence of learning is high, then the results of learning IPS is also high and vice versa if the independence of learning is low, then the results of learning IPS is also low. Thus, it can be said that any increase in self-reliance learning student's can improve students' IPS learning outcomes.

\section{c. Interaction Between Learning Model and Self-Reliance Learning to Student IPS Learning Outcomes}

The results showed that there is an interaction between the learning model and the independence of learning to the learning outcomes of IPS students. Interactions show that learning models and learning independence have an influence on students' IPS learning outcomes. The third hypothesis test obtained $F_{\text {count }}=3.64>F_{\text {table }}=2.77$. Thus, the hypothesis proposed is that there is an interaction between the learning model and the independence of learning to the learning outcomes of IPS students received empirically.

The findings of this study contained interactions between learning models and learning independence and influenced students' IPS learning outcomes. When viewed the average learning outcomes of IPS taught with the model of inquiry learning and high 
The Influence of Inquiry Learning Method and Self-Reliance Learning on IPS Outcomes...

learning independence is higher than the average learning outcomes of IPS students who are taught using conventional learning models. Then the average IPS learning outcomes of students who are taught with an inquiry learning model and low learning independence is higher than the average student's IPS learning outcomes taught using conventional learning models.

Every teaching and learning activity has a goal or purpose. This goal is gradual and tiered starting from a very operational and concrete model that is from the learning model and readiness of a student, one of which is the independence of learning owned by students. If a teacher uses an inquiry learning model with a state of high learning independence it will affect the learning outcomes of IPS, and if the teacher uses a conventional learning model with a state of low student learning independence will also affect the learning outcomes of IPS.

Thus it can be concluded that the learning model and learning independence significantly affect the student's learning outcomes. Students who have high learning independence will tend to behave in accordance with objects that can give high scores, therefore it can be said that students' IPS learning outcomes are influenced by the learning model and learning independence of a student in carrying out learning activities. This shows that significant learning independence factors distinguish students' IPS learning outcomes, where students' IPS learning outcomes with high self-reliance learning, both taught by applying the inquencing learning model and conventional learning models are higher than the learning outcomes of IPS students with low selfreliance learning.

\section{Conclusion}

The conclusions obtained from the results of the study stated that the learning outcomes of IPS students who are educated with the learning model of inquiry is higher than the results of students' IPS learning that is taught with conventional learning models. The average score of student IPS learning outcomes taught by the inquiry learning model is higher than the average student's IPS learning outcomes that are taught by conventional learning models.

Then on the learning outcomes of IPS students who have high self-reliance learning is higher than the learning outcomes of IPS students who have low self-reliance learning. The average score of IPS learning outcomes of students who have high self- 
reliance learning is higher than the average learning outcomes of IPS students who have low self-reliance learning.

Furthermore, there is an interaction between the learning method and the selfreliance of learning to the learning outcomes of IPS student. Students who have the selfreliance of high learning are more precisely taught by using the learning method of inquiry while for students who have low self-reliance learning is more precisely taught by using conventional learning models.

Based on the study of theory and referring to this research, in an effort to improve learning outcomes in social science subjects is to train learners to be active in the learning process by applying the learning model of inquiry, developing insights for teachers on learning strategies by using the learning model of inquiry, making inputs and consideration materials to educational personnel to be able to apply the model of inquiry learning in teaching and learning activities in various disciplines in the evaluation school and can be used as an improvement material in the independence of learning and learning outcomes in elementary school can then motivate teachers in finding and developing varied learning models that are tailored to the characteristics and age of students in order to improve the quality of education, especially in developing the 2013 Curriculum by conducting training in schools and the results of this research can increase knowledge so that it can be used as the basis for further research research.

\section{Bibliography}

Agustinawati, N. (2014). Pengaruh Metode Pembelajaran dan Kemandirian Belajar Terhadap Hasil Belajar Sejarah Siswa di SMAN 7 Cirebon. Jurnal Pendidikan Sejarah, 3(2), 1-7. doi:doi.org/10.21009/JPS.032.01

Aliyyah, R. (2017). Pengaruh kemandirian belajar terhadap hasil belajar IPA. Jurnal Sosial Humaniora, 8(2), 126 - 143.

Anderson, L. W., \& Krathwohl, D. R. (2001). A Taxonomy for Learning, Teaching, and Assesing: A Revision of Bloom's Taxonomy of Educatioanl Objectives. New York: Addison Wesley Longman, Inc.

Daulay, M. I. (2016). Penerapan Model Inkuiri dalam Meningkatkan Pembelajaran IPS di Kelas IV SDN 013 Tampan Pekanbaru. Jurnal Obsesi : Jurnal Pendidikan Anak Usia Dini, 2(1), 46-53. doi:doi.org/10.31004/obsesi.v2i1.48 
The Influence of Inquiry Learning Method and Self-Reliance Learning on IPS Outcomes...

Fraenkel, J., \& Wallen, N. (2008). How to Design and Evaluate Research in Education. New York: McGraw-Hill Higher Education.

Jonson Hulman Siburian, S. T. (2019). Pengaruh Strategi Pembelajaran Inkuiri dan Motivasi Berprestasi Terhadap Hasil Belajar Pelestarian Lingkungan Hidup. Jurnal Teknologi Pendidikan, 12(1), 62-74. doi:doi.org/10.24114/jtp.v12i1.14503

Lipton, L., \& Hubble, D. (2005). Menumbuhkembangkan Kemandirian Belajar: Mengoptimalkan Kecerdasan Baca-Tulis, Membangun Lingkungan Belajar, Mengevaluasi (1 ed.). (R. Muttaqin, Trans.) Bandung: Nuansa.

Meli, N. L. (2017). Penerapan Model Pembelajaran Inkuiri Terbimbing Untuk Meningkatkan Hasil Belajar IPS Siswa Kelas V SD No. 2 Canggu. Journal of Education Action Research, 1(3), 218-229. doi:dx.doi.org/10.23887/jear.v1i3.12686

Mince, M. T. (2017). Penerapan model pembelajaran inkuiri untuk meningkatkan hasil belajar ips siswa kelas V SD. Jurnal Pendidikan Guru Sekolah Dasar. 7(1).

Oktavera, S. (2015). Pengaruh Media Pembelajaran dan Kemandirian Belajar Terhadap Hasil Belajar IPA Siswa Kelas IV Sekolah Dasar. Jurnal Pendidikan Dasar, 6(2), 312 323. doi:doi.org/10.21009/JPD.062.13

Rahmadani, F. (2018). Pengaruh Metode Inkuiri dan Motivasi Belajar Terhadap Hasil Belajar IImu Pengetahuan Sosial Siswa di Kelas IV SD Swasta Pelangi Medan. LINGUISTIK: Jurnal Bahasa dan Sastra, 3(2), 193-206. doi:dx.doi.org/10.31604/linguistik.v3

Rodiyana, R. (2015). Pengaruh Penerapan Strategi Pembelajaran Inkuiri Terhadap Kemampuan Berpikir Kritis Dan Kreatif Siswa SD. Jurnal Cakrawala Pendas, 1(1).

Rohima. (2018). Pengaruh Model Pembelajaran dan Kemandirian Belajar Terhadap Hasil Belajar IPA Siswa Kelas V SD Al Ikhlash Taqwa Medan. Medan: Universitas Medan.

Suharnan. (2012). Pengembangan Skala Kemandirian. Jurnal Psikologi Indonesia, 1(2), 6676.

Surya, Y. F. (2017). Peningkatan Hasil Belajar Siswa IPS Menggunakan Model Inkuiri Sekolah Dasar. Lembaran IImu Kependidikan: Journal of Educational Research, 46(1), 12-15. 